\title{
Internalisasi nilai pendidikan kewarganegaraan pada tradisi pesta laut Blanakan dalam rangka pengembangan ideal democratic citizen
}

\section{Lili Halimah a, 1*, Anisah b, 2 \\ *korespondensi penulis

\begin{tabular}{ll}
\hline \multicolumn{2}{l}{ Informasi artikel } \\
\hline Sejarah artikel: & \\
Diterima & $: 19-10-2018$ \\
Revisi & $: 23-10-2018$ \\
Dipublikasikan & $: 31-10-2018$ \\
\hline
\end{tabular} \\ Kata kunci: \\ internalisasi nilai \\ pendidikan kewarganegaraan \\ pesta laut Blanakan \\ warga negara demokratis}

a, b Program Studi Pendidikan Pancasila dan Kewarganegaraan, STKIP Pasundan, Cimahi, Jawa Barat

${ }^{1}$ lili.halimah@gmail.com *; anianisah40@gmail.com \begin{abstract}
ABSTRAK
Pendidikan Kewarganegaraan memiliki tiga kompetensi yang dapat membentuk "the ideal democratic citizen" yakni kompetensi civic knowledge, civic skills, dan civic disposition. Pembelajaran PPKn mengaitkan antara teori dengan praktik nyata di lapangan, dan berhubungan dengan nilai-nilai budaya yang beragam dan majemuk. Faktor yang mempengaruhi nilai budaya lokal dalam melestarikan kebudayaan melalui upacara adat pesta laut Blanakan Kabupaten Subang Jawa Barat yang dilakukan setahun sekali guna menghormati leluhurmya. Rumusan masalah bagaimana pengembangan the ideal democratic citizen melalui aspek civic knowledge, civic skill, dan civic disposition pada tradisi pesta laut Blanakan? Penelitian ini menggunakan pendekatan kualitatif. Hasil penelitian (a) masyarakat nelayan memunculkan civic knowledge yang diarahkan oleh para tokoh, sehingga memiliki kesadaran untuk melestarikan nilai-nilai kebudayaan, yang mampu mengeksplorasi dan memanfaatkan potensi alam daerah, (b) nilainilai dalam pesta laut, selalu memerlukan civic skill yang cakap dalam mengorganisasikan kegiatan, semua ini diperlukan participatory skill, dan (c) membentuk karakter masyarakat nelayan pada pesta laut, dengan cara memberi tahu dan mengajarkan hal-hal yang baik oleh para tokoh budaya. Dengan demikian perlu ditanamkan the ideal democratic citizen untuk meningkatkan kecintaan pada nilai budaya lokal, dan tidak terpengaruh oleh budaya asing.

\section{ABSTRACT}

Keywords:

value internalization

civic education

Blanakan sea fest

ideal democratic citizen
Civic Education has three competencies that can form "the ideal democratic citizen" namely the competence of civic knowledge, civic skills, and civic disposition. Civic Education learning links theory with real practice in the field, and relates to diverse and diverse cultural values. Factors that influence the value of local culture in preserving culture through the traditional ceremony of the Blanakan sea party in Subang, West Java, are conducted once a year to honor their ancestors. Formulation of the problem of how to develop the democratic citizen ideal through civic knowledge, civic skills, and civic disposition in the Blanakan sea party tradition? This study uses a qualitative approach. The results of the study (a) The fishing community raises civic knowledge that is directed by the characters, so that they have the awareness to preserve cultural values, which are able to explore and utilize the natural potential of the region, $(b)$ the values in the sea party, always need the skill competent in organizing activities, all this is required partipatory skills, and (c) Forming the character of the fishing community at sea parties, by telling and teaching good things by cultural figures. Thus, it is necessary to instill the democratic citizen ideal to increase the love of local cultural values, and not be influenced by foreign culture.

\section{Copyright $\odot 2018$ Lili Halimah dan Anisah}

\section{Pendahuluan}

Sumber daya manusia merupakan prasyarat mutlak dalam mencapai tujuan pembangunan pada era globalisasi dan pendidikan merupakan salah satu syarat pengembangan sumber daya manusia yang berkualitas tinggi. Salah satu program pengajaran dalam pendidikan, memiliki 
peranan yang penting dalam membentuk warga negara yang berkualitas yakni melalui mata pelajaran Pendidikan Pancasila dan Kewarganegaraan (PPKn) memfokuskan pada pembentukan warga negara yang memahami dan mampu melaksanakan hakhak dan kewajibannya untuk menjadi warga negara yang cerdas, terampil, berkarakter sesuai dengan Pancasila dan UUD 1945.

Warga negara yang baik merupakan tujuan yang diharapkan oleh PPKn. Dalam bidang kajian ilmiah dan akademik, PPKn tidak hanya terdiri dari pengetahuan, nilai dan keterampilan, tetapi juga mencakup penerapan pengetahuan, nilai, dan keterampilan dalam situasi kehidupan nyata dengan berpartisipasi secara aktif (Doğanay, 2012). Peran Pendidikan Kewarganegaraan secara substantif tidak saja mendidik generasi muda menjadi warga negara yang cerdas dan sadar akan hak dan kewajibannya dalam konteks kehidupan bermasyarakat, berbangsa, dan bernegara yang merupakan penekanan dalam istilah pendidikan kewarganegaraan, melainkan juga membangun kesiapan warga negara untuk menjadi warga dunia (global society). Maka sudah seharusnya masalah ini menjadi tanggung jawab bersama yaitu, keluarga, guru dan masyarakat. Karena merekalah orang-orang terdekat dengan siswa, terutama guru sebagai pendidik dan mata pelajaran PPKn yang mengajarkan nilai dan moral.

Materi pembelajaran PPKn mengaitkan antara teori dengan praktik yang terjadi di lapangan atau dalam kondisi nyata, hal ini pula ada hubungannya dengan nilai-nilai budaya bangsa Indonesia yang sangat beragam dan majemuk, seperti ras, suku, bahasa, etnis, dan lain-lain. Oleh karena itu, kebudayaan merupakan salah satu pencerminan dari karakteristik dalam sebuah masyarakat dalam hubungannya dengan alam, kuat, berbahaya dan banyak. Manusia dengan alam sejak awal kehadirannya beradaptasi dengan alam karena manusia memiliki akal dan naluri untuk menjaga harmoni dengan alam sekitarnya (Daeng, 2008).

Masyarakat Blanakan adalah salah satu dari masyarakat Indonesia yang masih peduli terhadap kebudayaan lokal yang diwariskan oleh nenek moyang. Kearifan lokal mengandung nilai yang menghargai lingkungan alam tempat masyarakat tinggal. Harmoni dengan alam merupakan keharusan untuk menjaga eksistensi mereka sehingga tertata secara ajek dalam suatu tatanan adat istiadat suatu masyarakat.

Nilai-nilai yang diwariskan dan dipraktikkan dalam masyarakat adat merupakan cara yang baik untuk memelihara kelangsungan harmoni dengan alam dan sesama masyarakat adat masih relevan di zaman post-modern (Indrawardana, 2012). Pesta laut Blanakan merupakan salah satu tradisi masyarakat setempat yang mampu bertahan dalam pengaruh kebudayaan asing pada zaman sekarang ini, serupa dengan apa yang dikemukakan oleh Wale mengenai local genius yang menjadi benteng budaya lokal terhadap pengaruh luar (Rosidi, 2011).

Oleh karena itu kebudayaan lokal harus tetap ada sebagai patokan cara berpikir dalam bertingkah laku masyarakat setempat, dan sebagai filter arus globalisasi yang dipermudah oleh teknologi sehingga mudahnya budaya asing masuk ke tengahtengah budaya kita. Untuk tetap ada dibutuhkan sebuah strategi untuk memberdayakan pengetahuan lokal membutuhkan pemahaman tidak hanya merepresentasi pengetahuan lokal itu, namun juga secara epistemologi diakui dan direkonstruksi makna yang tersurat maupun tersirat (Nygren, 2009).

Dengan mewariskan kebudayaan kepada generasi muda dapat menjadi salah satu penopang keberadaan kebudayaan lokal, salah satu cara pewarisannya dapat dengan cara memberi pengetahuan tentang suatu tradisi dan menjelaskan nilai-nilai luhur yang terkandung dalam suatu tradisi tersebut agar para generasi muda tertarik dan ikut serta dalam melestarikan kebudayaan asli daerahnya. Seperti halnya masyarakat Blanakan yang mewariskan kebudayaan pesta lautnya secara turun-temurun sebagai pelestarian kebudayaan yang mereka miliki dari para nenek moyang.

Mengingat pentingnya nilai-nilai budaya bangsa Indonesia di era globalisasi perlu dipertahankan supaya tidak hilang. Namun 
perlu juga dilestarikan untuk menjadi ikon obyek wisata dunia. Guna meningkatkan nilai devisa bangsa Indonesia, terutama pada sektor industri pariwisata. Hal itu yang menarik peneliti untuk mengkaji penelitian ini adalah bahwa kehidupan manusia saat ini jauh berubah dari kehidupan masyarakat sebelumnya. Kemajuan ilmu pengetahuan dan teknologi telah membawa manusia ke dalam kehidupan modern dan globalisasi. Akan tetapi masyarakat Blanakan masih menyelenggarakan pesta lautnya walaupun kehidupan masyarakat sudah berubah dan mengikuti perkembangan zaman.

Berdasarkan pada latar belakang masalah di atas, maka peneliti hanya fokus pada nilainilai pendidikan kewarganegaraan, yakni: civic knowledge, civic skills, dan civic disposition. yang menjadi dasar pengembangan The Ideal Demokractic Ciizen pada tradisi pesta laut Blanakan.

\section{Metode}

Pendekatan kualitatif dengan metode studi etnografi dugunakan untuk mengumpulkan data dan menganalisis data dalam penelitian ini. Metode etnografi adalah prosedur penelitian kualitatif untuk menggambarkan, menganalisa, dan menafsirkan unsur-unsur dari sebuah kelompok budaya seperti pola perilaku, kepercayaan, dan bahasa yang berkembang dari waktu ke waktu (Creswell, 2009). Metode etnografi memberikan gambaran secara mendetail mengenai latar belakang dan sifatsifat khas dari suatu upacara pesta laut Blanakan pada masyarakat Desa Blanakan. Alasan penelitian ini dilakukan karena masyarakat Blanakan masih mempertahankan budaya lokal pesta laut Blanakan hingga kini meskipun arus globalisasi deras mengalir.

Subjek dari penelitian ini adalah sumber yang dapat memberikan informasi, yakni tokoh pendidikan di daerah setempat, tokoh budaya, atau sesepuh yang mengetahui sejarah pesta laut Blanakan, dan masyarakat nelayan di Desa Blanakan yang terkait. Pengalaman warga nelayan yang telah langsung melakukan kegiatan tradisi pesta laut. Sumber yang dapat memberikan informasi yang utama adalah tokoh adat yang biasa ditunjuk untuk menjadi juru kunci pada saat pesta laut Blanakan berlangsung karena tokoh tersebut banyak mengetahui tentang upacara adat pesta laut Blanakan, adapun sumber pendukung untuk menguatkan informasi adalah sebagian masyarakat.

\section{Hasil dan Pembahasan}

Desa Blanakan merupakan salah satu desa di Kecamatan Blanakan Kabupaten Subang Provinsi Jawa Barat Desa Blanakan merupakan desa pesisir yang tidak jauh dengan Laut Jawa dan sebagian besar lahan persawahan oleh karena itulah, mayoritas masyarakat Desa Blanakan bermata pencaharian sebagai nelayan dan petani. Upacara pesta laut Blanakan terlahir karena keinginan masyarakat nelayan sebagai rasa syukur kepada Tuhan atas rezeki yang melimpah selama satu tahun dan penghormatan kepada hantu penghuni laut atas keselamatan selama melaut menurut kepercayaan masyarakat nelayan Desa Blanakan yang masih mempercayai hal-hal tradisional tersebut.

Tradisi pesta laut Blanakan adalah acara tahunan yang dimiliki masyarakat nelayan Blanakan sebagai ungkapan rasa syukur kepada tuhan atas rezeki yang diberikan kepada masyarakat nelayan baik dalam bentuk keselamatan saat melaut maupun hasil laut yang melimpah sepanjang tahun lalu, pesta laut Blanakan serupa halnya dengan upacara adat Nandran pada masyarakat Eretan Cirebon dan daerah pesisir lainnya sebagai ungkapan rasa syukur kepada Tuhan, selain itu tradisi pesta laut Blanakan memang sudah turun-temurun dari nenek moyang yang sampai saat ini masih dijaga dan dilaksanakan.

Faktor yang mendorong tradisi pesta laut masyarakat Blanakan masih mempertahankan tradisi ini adalah warisan budaya dari leluhur. Tradisi pesta laut Blanakan merupakan salah satu kepercayaan masyarakat nelayan Blanakan terhadap hantu penghuni laut.

Tradisi pesta laut Blanakan adalah merupakan hasil dari karya manusia yang turun-temurun seperti adat, kebiasaan, kepercayaan, ajaran dan sebagainya. Agar tradisi pesta laut Blanakan ini dapat terus di 
wariskan bukan saja menjadi tradisi yang turun temurun untuk memperingati ucapan rasa syukur masyarakat terhadap hasil laut yang didapat, akan tetapi pesta laut Blanakan juga dapat dijadikan sebuah budaya yang bernilai dalam sebuah masyarakat.

Sejarah ruwatan laut diambil dari keangkeran alas jengki yakni istilah hutan yang terletak di tengah pesisir laut yang masih banyak dihuni habitat monyet atau kera, sementara desa Blanakan desa pesisir yang lokasinya memanjang dari arah selatan ke utara dan mengikuti aliran sungai Ciasem, oleh sebab itu kebanyakan penduduknya berprofesi sebagai nelayan. Dan beberapa tahun yang lalu masyarakat desa mengenal keberadaan hutan yang menurut para orang tua disebut alas jengki, karena pertama, hutan yang banyak dihuni oleh monyet dan kera, kedua, waktu dulu menyimpan banyak cerita misteri karena banyak binatang liar dan keberadaan kerajaan yang gaib diyakini oleh masyarakat nelayan, dan sebagian masyarakat yang tergolong menganut kepercayaan animisme dan dinamisme.

Selain itu, ada yang meyakini bahwa monyet yang berkeliaran di hutan alas jengki tersebut adalah siluman atau makhluk jadijadian, sementara menurut orang pintar atau guru spiritual sebagian masyarakat pesisir sebenarnya sudah berada di bawah kekuasaan monyet atau kera, dan agar desa ini bisa tenang dan terhindar dari marabahaya yaitu dengan cara harus diadakannya ritual karena waktu dulu sering diadakan ritual-ritual tertentu pada saat menjelang ruwatan laut.

Sejarah ruwat laut Blanakan diambil dari sebuah nama hutan di Pesisir Muara Ciasem Subang, yang pada saat itu masyarakat mempercayai bahwa daerah tersebut mempunyai peran penting atau pengaruh terhadap kehidupan warga sekitar karena dianggap sakral. Masyarakat pada saat itu masih menganut paham dinamisme dan animisme yang pada saat ini kepercayaan tersebut menghasilkan sebuah tradisi dan sistem pengetahuan lokal.

Sistem pengetahuan lokal atau indigenous knowledge merupakan konsep tentang gejala yang dapat dilihat, dirasakan, dan dialami dan direkonstruksi menurut pola dalam masyarakat tertentu (Rosyadi, 2014). Kemampuan berpikir dapat menghasilkan sebuah konsep yang dihasilkan dari sebuah pengamatan, pengalaman, komunikasi ataupun berlandaskan sebuah keyakinan, seperti apa yang dilakukan oleh masyarakat Blanakan, mereka membuat sebuah tradisi berdasarkan keyakinannya terhadap sebuah tempat yang dianggap sakral.

Masyarakat memerlukan kecakapan (civic skill) dalam melakukan ritual sesuai nilai budaya setempat, agar para nelayan yang mencari ikan di daerah Blanakan selalu mendapatkan hasil tangkapan yang banyak dan tidak mendapatkan gangguan dari makhluk gaib. Pada saat itu para sesepuh dan tokoh desa akan menggelar ritual dan sesajen di sekitar alas jengki yang pada saat itu masih berupa hutan yang lebat di tengah laut dan sesajennya yaitu berupa makanan, minuman, bunga, kepala kerbau, darah kerbau, dan kemenyan yang biasa di sajikan pada saat ritual pesta laut.

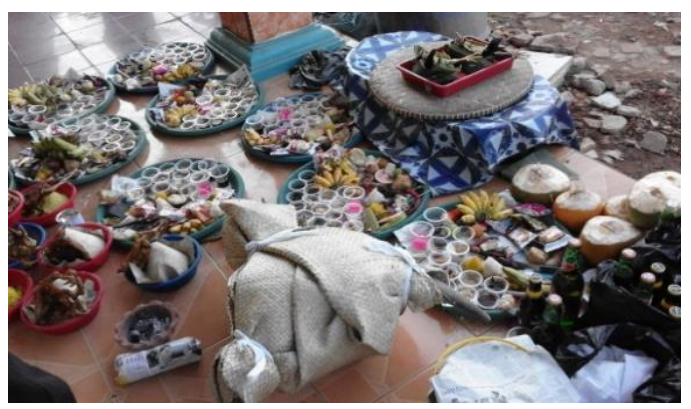

Gambar 1. Sesajen untuk Melengkapi Upacara

Berdasarkan penelitian yang dilakukan, dalam kegiatan pesta laut Blanakan, dapat diambil sebuah nilai atau keterampilan dengan melakukan ritual tersebut, masyarakat nelayan dapat mencari ikan dengan mudah, dan terhindar dari marabahaya, kegiatan pesta laut juga dirasakan masyarakat sekitar sebagai icon budaya yang menghasilkan sebuah tradisi secara turun temurun.

Pesta laut Blanakan yang ke-50 merupakan agenda tahunan yang dilaksanakan oleh masyarakat pesisir pantai utara Jawa. Pesta laut masyarakat pesisir di Blanakan dilaksanakan setiap musim ikan normal atau berdasarkan temurun seperti hitungan Jawa. Namun jika dijabarkan secara rasional, musim ikan normal maka jumlah 
tangkapan ikan yang diperoleh nelayan akan lebih besar dikarenakan ombak yang relatif tenang maka populasi ikan melimpah di daerah muara. Selain untuk berlindung dan mencari makan, ikan juga berkembang biak di muara pada musim ini. Sedangkan pada bulan Januari hingga Maret, ombak tergolong besar sehingga populasi ikan akan bermigrasi dari Laut Jawa ke perairan yang lebih tenang.

Pelaksanaan tradisi pesta laut Blanakan ke-50 bertempat di dermaga dan Tempat Pelelangan Ikan (TPI) Blanakan yang secara penuh dikelola oleh Koperasi Unit Desa (KUD) Mandiri Mina Fajar Sidik. Pertimbangan lokasi pelaksanaan di lokasi tersebut karena dermaga dan TPI ini merupakan pusat kegiatan perekonomian masyarakat lokal yang tidak pernah libur, kecuali hari raya dan hari pelaksanaan tradisi pesta laut Blanakan.



Gambar 2. Pengurus KUD (Koperasi Unit Desa) Mandiri Mina Fajar Sidik

Pelaksana tradisi pesta laut Blanakan ke50 ini adalah anggota KUD yang bekerja sama dengan salah satu produk rokok sebagai sponsor. Undangan yang dibuat oleh penyelenggara melibatkan Bupati Subang dan jajarannya, Kepala Dinas Perikanan dan Kelautan Subang, Kamar Dagang Industri dan Perdagangan Bidang Perikanan dan Kelautan, Instansi Militer dan berbagai instansi terkait.

Peserta yang terlibat pada acara ini berasal dari Blanakan, Indramayu, Karawang, Purwakarta dan daerah sekitarnya. Namun jumlah peserta acara Pesta Laut tahun ini menurun drastis, dikarenakan adanya insiden yang berujung meninggalnya seorang pemuda karena kepalanya dilempar botol minuman keras. Maka dari itu, penyelenggara berusaha meminimalkan kemungkinan terjadinya kejadian tersebut dengan mendatangkan aparat keamanan.

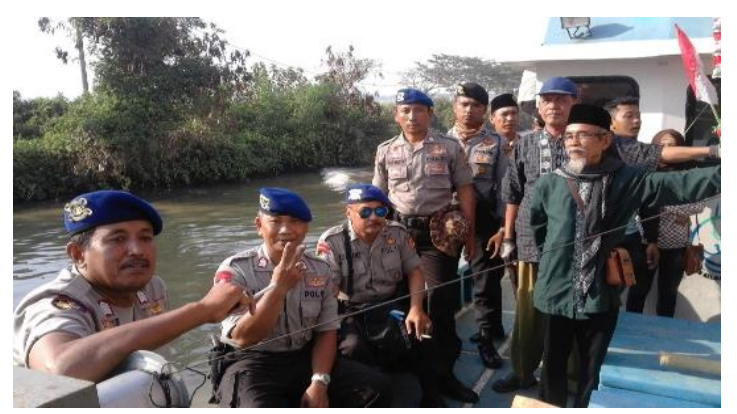

Gambar 3. Persiapan ke Amanan Saat

Perahu Dongdang Akan di Lepas

Prosesi pelaksanaan tradisi pesta laut Blanakan berlangsung selama satu minggu, terhitung sejak tanggal 10 hingga 18 September 2017. Acara dimulai dengan persiapan perahu, dongdang, penyebaran undangan, persiapan wayang kulit, persiapan sunatan massal dan berbagai acara lainnya. Puncak dari pelaksanaan tradisi pesta laut Blanakan atau ruat laut Blanakan ini adalah pada tanggal 17 september 2017 pada saat Dongdang dibuat oleh masyarakat yang berisi kepala kerbau yang disembelih dan sesajen pada bambu yang telah dirangkai sedemikian rupa untuk di larung ke laut Jawa serta diarak oleh perahu nelayan seluruh masyarakat Blanakan.

Pesta laut Blanakan merupakan kegiatan dan keinginan dari hasrat masyarakat nelayan untuk mencari ketentraman dalam diri masing-masing dengan cara yang sudah ditradisikan dalam tradisi tersebut mengandung kepercayaan tradisional yang menyangkut kepada emosi keagamaan dan pandangan hidup setiap masyarakatnya. Selaras dengan yang dikemukakan oleh Yogi (2013), pesta laut sebagai upacara atau pesta adat sebagai bentuk kegiatan manusia dalam hidup bermasyarakat yang didorong oleh hasrat untuk memperoleh ketentraman batin atau mencari keselamatan.

Dengan memenuhi tata cara yang dijadikan tradisi masyarakat, bentuk upacara atau pesta adat yang berkaitan dengan adat dan kehidupan beragama, mencerminkan sistem kepercayaan akan pikiran serta pandangan hidup masyarakat. Upacara yang dilakukan merupakan aktivitas tetap dari 
masyarakat pada kurun waktu tertentu yang secara keseluruhan melibatkan masyarakat sebagai pendukungnya.

Pesta laut Blanakan merupakan suatu sistem gotong-royong masyarakat Blanakan yang diwujudkan dalam kegiatan sakral dalam menyiapkan sesaji maupun melarungkan sesaji ke tengah laut, dari kegiatan tersebut terdapat nilai religi dan nilai sosial yang positif untuk kehidupan bermasyarakat. Pesta laut Blanakan ini mengandung nilai-nilai, norma-norma dan aturan yang berguna bagi kehidupan masyarakat sehingga budaya ini akan menciptakan hubungan kekeluargaan yang erat dan pada akhirnya akan terwujud semangat persatuan dan kesatuan di masyarakat.

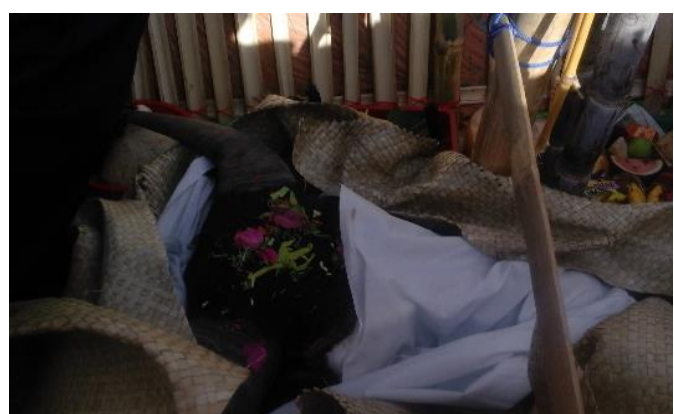

Gambar 4. Kepala Kerbau Sebagai Simbol Upacara

Hal ini dapat dilihat ketika masyarakat Blanakan mempersiapkan perayaan pesta laut, kemudian diaplikasikan dalam kehidupan sehari-hari, masyarakat bergotong royong dan bekerja sama terlihat dalam mempersiapkan segala bentuk perlombaan masyarakat bergotong royong membuat perahu kecil "dongdang" dan membuat sesaji pada acara puncak dari kegiatan tersebut mampu menciptakan keakraban dan kebersamaan diantara masyarakat dan akhirnya terwujud semangat persatuan dan kesatuan diantara masyarakat Blanakan.



Gambar 5. Acara Baritan (Do'a dan Makan Bersama digelar Satu Hari Menjelang Acara
Pelaksanaan) dalam rangka memanjatkan Do'a dan Rasa Syukur Para Nelayan.

Gambar di atas menunjukkan kegiatan sebelum melaksanakan upacara pesta laut Blanakan, masyarakat melaksanakan acara baritan atau doa dan makan bersama berfungsi untuk kelancaran acara dan menyerahkan semua acara kepada Tuhan Yang Maha Esa agar senantiasa diberi berkah dengan mengadakan ritual tersebut, selain itu pesta laut Blanakan mampu menciptakan masyarakat bergotong royong dan bekerja sama terlihat dari kekompakan masyarakat Blanakan melakukan tradisi ini.

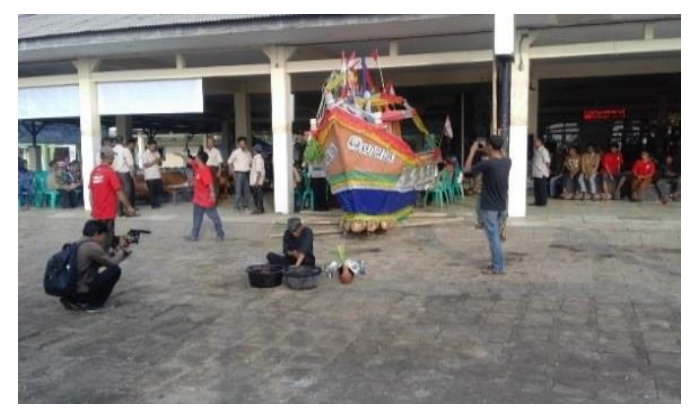

Gambar 6. Proses Pelepasan Perahu Kecil (Dongdang)

Gambar di atas menunjukkan bukti kerja sama masyarakat nelayan Desa Blanakan dalam pelepasan perahu dongdang yang akan dibuang ke tengah laut. Perahu dongdang diangkat oleh masyarakat nelayan Desa Blanakan untuk dibawa kedalam perahu nelayan dan perahu dongdang berisikan sesajen berupa bunga-bunga, kepala kerbau, yang nantinya akan dihanyutkan ke tengah laut oleh masyarkat nelayan.

Manusia hanya dapat berkembang sebagai manusia seutuhnya hanya bila ia berada dalam kelompok. Manusia sebagai makhluk sosial, secara asasi merupakan sesuatu yang tidak dapat ditolak (Marx, 1999). Manusia hanya dapat berkembang sebagai manusia seutuhnya hanya bila ia berada dalam kelompok. Sociability manusia lebih dari sekadar pengertian bahwa manusia membutuhkan yang lainnya untuk memenuhi kebutuhannya. Marx melihat manusia sebagai human social animal yang dapat berkembang secara pribadi dalam sebuah kelompok masyarakat (1999).

Jurnal Civics: Media Kajian Kewarganegaraan |153 
Tradisi pesta laut Blanakan merupakan agenda tahunan yang dilaksanakan oleh masyarakat pesisir pantai utara jawa di kecamatan Blanakan Kabupaten Subang Jawa Barat. Pesta laut masyarakat pesisir di Blanakan dilaksanakan setiap musim ikan normal atau berdasarkan hitungan Jawa. Masyarakat Blanakan merupakan masyarakat Indonesia yang masih peduli terhadap kebudayaan lokal yang diwariskan oleh nenek moyang, Pesta Laut Blanakan ini mengandung nilai-nilai, norma-norma dan aturan yang berguna bagi kehidupan masyarakat sehingga budaya ini akan menciptakan hubungan kekeluargaan yang erat dan pada akhirnya akan terwujud semangat persatuan dan kesatuan di masyarakat.

Nilai-nilai budaya pada tradisi pesta laut Blanakan adalah nilai budaya gotong-royong. Adapun salah satu kegiatan yang mengandung gotong-royong bisa dilihat dalam kegiatan membuat perahu dongdang yang dilakukan secara bersama-sama demi mewujudkan keinginan masyarakat nelayan untuk melaksanakan pesta laut Blanakan. Nilai-nilai budaya pada tradisi pesta laut Blanakan adalah menjalin tali silaturahmi yang dapat dilihat saat para nelayan tidak melaut demi melaksanakan atau mengikuti berlangsungnya pesta laut Blanakan.

Pesta laut Blanakan juga mengandung nilai religius yang merupakan kepercayaan atau keyakinan manusia, tertinggi serta mutlak. Dalam acara pesta laut Blanakan mengandung berbagai nilai ketuhanan yang berawal dari sebuah kepercayaan tertinggi masyarakat dalam menyerahkan hasil laut ataupun kegiatan mencari ikan di laut agar hasil tersebut dapat berlimpah dan berkah bagi masyarakat Blanakan.

Pesta laut Blanakan selain mempunyai nilai religius yang menganggap bahwa dengan mengadakan acara ini membawa berkah pesta ini juga bernilai ekonomi. Nilai dari sebuah tradisi tersebut dianggap bernilai bagi masyarakat, pesta laut tersebut membawa keuntungan bagi pihak masyarakat karena dijadikan icon pariwisata baik domestik maupun mancanegara. Selain itu, pesta laut Blanakan memiliki nilai gotong-royong dan mempererat tali silaturahmi. Nilai religius jelas sekali terdapat dalam pesta laut Blanakan karena tujuan utama dalam pesta laut Blanakan adalah mengucap rasa syukur kepada Tuhan Yang Maha Esa. Nilai gotongroyong terlihat saat sebelum pelaksanaan pesta laut Blanakan, diadakan musyawarah antara anggota nelayan dengan segenap pengurus Koperasi Unit Desa (KUD) Mina Fajar Sidik untuk bekerja sama, membagi tugas tiap kelompok demi kelancaran acara pesta laut Blanakan.

Selain itu, terlihat kegiatan gotongroyong dalam pembuatan perahu dongdang yang di kerjakan bersama-sama oleh masyarakat nelayan dengan suka ria, di dalam kegiatan membuat dongdang terlihat rasa kebersamaan yang erat karena masyarkat bekerja tanpa pamrih demi terlaksananya pesta laut Blanakan. Pesta laut Blanakan juga sebagai jembatan mempererat tali silaturahmi antara masyarakat nelayan Blanakan dengan masyarakat nelayan luar Blanakan, karena dalam kegiatan tersebut masyarakat dari Blanakan maupun luar desa diperbolehkan untuk menyaksikan atau mengikuti acara tersebut untuk menjalin silaturahmi dan memeriahkan acara tersebut.

Dalam tradisi pesta laut Blanakan terdapat nilai-nilai budaya yakni nilai religius, nilai gotong royong dan nilai mempererat silaturahmi yang merupakan manifestasi dari kebudayaan. Kebudayaan tumbuh secara sosial oleh masyarakat (Darwis, 2008). Budaya ada karena hasil kegiatan atau keseharian masyarakat yang menghasilkan suatu kebudayaan, maka dari itu budaya dapat di ciptakan oleh masyarakat itu sendiri, dan kita sebagai manusia yang terus mempelajarinya dan melestarikan (mewariskan antar generasi) kebudayaan tersebut agar tidak punah terbawa arus globalisasi yang modern di zaman sekarang (Supardan, Hasan, \& Rachmatika, 2008).

Nilai-nilai budaya terdiri dari nilai yang menentukan identitas, kegunaan, agama, kuasa, dan solidaritas yang menjelma dalam cinta, persahabatan, dan gotong royong (Niode, 2007). Nilai-nilai budaya yang positif terkandung dalam pesta laut Blanakan di antaranya yaitu nilai gotong royong, 
kebersamaan, dan mempererat tali silaturahmi. Nilai-nilai tersebut dapat bermanfaat bagi masyarakat untuk kehidupan pada masa yang akan datang menjadi hidup lebih baik lagi, karena kita ketahui perubahan zaman kian pesat sehingga dapat menciptakan kebudayaan baru yang mempengaruhi kebudayaan lama. Oleh karena itu, nilai-nilai luhur yang terkandung dalam pesta laut Blanakan harus dijaga keutuhannya sehingga tidak tergerus oleh arus globalisasi yang bisa menjadi faktor lunturnya budaya lokal.

Aspek civic knowledge pada tradisi pesta laut Blanakan menyangkut kemampuan akademik keilmuan yang dikembangkan dari berbagai teori atau konsep politik, hukum, dan moral. Nilai Pendidikan Kewarganegaraan, dilihat dari aspek pengetahuan kewarganegaraan yang terdapat dalam sebuah pesta laut Blanakan melalui bagaimana pengetahuan warga negara itu sendiri seperti. Warga negara adalah anggota negara atau bangsa yang diakui secara hukum (Engle \& Ochoa, 1988).

Kewarganegaraan merupakan perjuangan politik yang seringkali dijabarkan dalam dua aspek penting, yakni pertama, sebagai status legal, dan kedua, kewarganegaraan sebagai praktik (Osler \& Starkey, 2005). Dalam batas legal, seorang warga negara adalah makhluk yang bertindak menurut hukum dan memiliki hal untuk mendapatkan perlindungan negara, dan sebagai praktik merujuk pada status warga negara sebagai agen politik (Kalidjernih, 2011). Dalam konteks anggota dari sebuah negara, maka dapat kemukakan mengenai kewarganegaraan adalah hubungan antara individu dan negara dan menghasilkan hak dan tanggung jawab tertentu, yakni termasuk hak untuk didengar dan untuk berpartisipasi dalam pemerintahan mereka sendiri, hak untuk perlindungan hukum yang sama, dan hak atas kebebasan dasar seperti kebebasan beragama dan berbicara (Doğanay, 2012).

Dengan demikian, warga negara merupakan sebuah kelompok dalam satu wadah yang mempunyai sebuah tujuan yang nantinya akan dilaksanakan secara bersamasama. seperti dalam pesta laut Blanakan warga negara ikut serta dalam melestarikan sebuah budaya atau tradisi yang mereka anggap sangat bernilai pada masyarakat Blanakan.

Pesta laut Blanakan bukan hanya sekadar sebuah tradisi di masyarakat, melainkan pengetahuan sebuah warga negara akan pentingnya sebuah budaya yang menghasilkan pengetahuan mengenai demokrasi. Dengan mengadakan pesta laut Blanakan, pengetahuan demokrasi dalam masyarakat bisa dirasakan seperti adanya sebuah aturan yang melekat dalam kegiatan tersebut yang membentuk rakyat atau masyarakat untuk ikut serta dalam kegiatan tersebut karena acara pesta laut Blanakan diselenggarakan untuk kepentingan warganya, dan demi kesejahteraan warga Blanakan itu sendiri.

Pendidikan kewarganegaraan tidak hanya terdiri dari pengetahuan, nilai dan keterampilan, tetapi juga mencakup penerapan pengetahuan, nilai, dan keterampilan dalam situasi kehidupan nyata dengan berpartisipasi secara aktif (Doğanay, 2012). Belajar demokrasi harus dimaknai sebagai proses yang fluktuatif berdasar pada pengalaman positif maupun negatif. Belajar demokrasi dan kewarganegaraan juga bukan semata-mata hasil dari pengalaman di sekolah tetapi juga yang diperoleh dalam konteks kehidupan sehari-hari, baik di lingkungan keluarga, masyarakat, tempat kerja dan lainlain (Suyato, 2016).

Selain nilai demokrasi, pesta laut Blanakan dapat mengandung nilai-nilai pendidikan kewarganegaraan. Oleh karena itu, kegiatan seremonial upacara adat pesta laut Blanakan itu bukan hanya sekadar pesta pada umumnya, tetapi memiliki nilai budaya yang sakral warisan leluhurnya. Untuk kepentingan ini paling tidak masyarakat nelayan memunculkan civic knowledge pengetahuan dasar tentang kebangsaan dan kewarganegaraan yang tentunya dapat diarahkan oleh para tokoh masyarakat.

Selain itu, nilai Pendidikan Kewarganegaraan juga memiliki nilai religius dan peduli lingkungan, hal ini terbukti pada acara pesta laut Blanakan itu sendiri, seperti sebelum kegiatan dimulai, para tokoh melakukan doa bersama memohon agar 
kegiatan tersebut, diberi kelancaran serta dapat bersahabat dengan lingkungan sekitar laut. Dengan pengetahuan dasar yang memadai, masyarakat paham dan mengerti dan dapat memberi sebuah kontribusi atau partisipasi dalam menjaga lingkungan, melalui pelarangan membuang limbah yang mengandung polusi sekitar laut. Perlindungan terkait lingkungan hidup merupakan kajian kewarganegaraan.

Partisipasi warga negara dalam menjaga kelestarian lingkungan hidup menjadi elemen yang penting karena warga negara menjadi bagian dari lingkungan hidup sendiri. Misalnya isu dampak pencemaran lingkungan hidup yang terjadi di masa saat ini menjadi hal yang menarik untuk dikaji terutama pengkajian dengan melihat partisipasi warga negara yang menjadi bagian dari isu tersebut (Aulia, Arif, \& Arpannudin, 2018).

Dengan demikian partisipasi masyarakat dalam pelaksanaan upacara adat pesta laut Blanakan tersebut menjadi sebuah peristiwa budaya yang sakral, menurut mereka selalu dikenang sepanjang waktu. Cara mereka menunjukkan bahwa nilai-nilai pendidikan kewarganegaraan itu dapat terwujud, terlaksana, apabila mereka melaksanakan upacara adat tersebut. Dengan demikian, muncul adanya unsur kontribusi (pengetahuan dasar) yang tertuang pada nilai-nilai religius dengan meningkatkan rasa syukur kepada Tuhan Yang Maha Esa. Masyarakat juga turut serta peduli pada kegiatan sosial melalui bermusyawarah untuk mendukung terlaksananya upacara adat pesta laut agar berjalan lancar sesuai harapan.

Oleh karena pengetahuan dasar nilai-nilai pendidikan kewarganegaraan, perlu dimiliki dalam rangka kegiatan tradisi pesta laut, agar masyarakat nelayan memiliki kesadaran dapat memelihara dan melestarikan nilai-nilai budaya secara turun menurun. Di pihak lain, tradisi pesta laut Blanakan merupakan suatu keunggulan daerah yang mempunyai potensi nilai budaya sebagai kearifan lokal yang perlu dikembangkan. Melalui berbagai pemikiran para tokoh masyarakat yang peduli, bahwa potensi kebudayaan ini perlu adanya pemikiran atau wawasan pengetahuan tentang hak dan tanggung jawab warga negara untuk dapat dilestarikan, prinsip-prinsip dan proses demokratis lebih rukun, lebih harmonis, lebih saling merekatkan rasa kekeluargaan. Kegiatan pesta laut ini, sangat bermakna karena berkumpulnya warga setempat maupun terdapat pula warga dari luar daerah, untuk dapat saling bertemu, saling bersosialisasi, saling bercengkrama, berbagi pengalaman, dan lain-lain.

Pengembangan warga negara yang bersifat demokratis dengan aspek civic knowledge dapat dilakukan salah satunya melalui tradisi pesta laut Blanakan, karena upacara adat ini merupakan sumber daya lokal hasil dari ciptaan dan karya akal manusia. Akal manusia dapat terwujud, apabila memperoleh pengetahuan yang memadai, terutama pendidikan kewarganegaraan. Dengan demikian, pengetahuan dasar sangat diperlukan dalam memelihara kegiatan upacara adat pesta laut, karena pengetahuan salah satu bagian dari nilai-nilai budaya bangsa Indonesia.

Metode yang dianggap paling tepat dalam menyampaikan materi kepada masyarakat nelayan dalam rangka penyelenggaraan acara seremonial pesta laut Blanakan, adalah metode ceramah, dengan pendekatan contextual teaching learning, karena metode tersebut sangat mudah diterima atau dicerna. Alasannya, metode ceramah ini gunakan itu sekaligus mendorong atau mengarahkan masyarakat untuk terjun langsung kelapangan dan mereka mengetahui sendiri apa keberadaan tradisi pesta laut Blanakan yang sebenarnya, dengan demikian mereka mengetahui dimana letak yang mengandung nilai-nilai pendidikan kewarganegaraan.

Dengan pengetahuan dasar yang memadai sehingga civic knowledge dapat diperoleh hasil yang cukup memuaskan dalam kegiatan acara tradisi pesta laut Blanakan, setidaknya dapat mempertahankan nilai-nilai budaya dengan cara melestarikannya sepanjang massa. Nilai-nilai pendidikan kewarganegaraan dapat memiliki pengetahuan tentang kebangsaan dan kewarganegaraan, hal ini menyangkut kemampuan akademik keilmuan yang dikembangkan berbagai teori, atau lebih dikenal dengan nama civic knowledge 
(Soemantri, 2001) Salah satu perwujudan nilai-nilai pendidikan kewarganegaraan adalah pada acara tradisi pesta laut Blanakan. Oleh karena itu, masyarakat nelayan paling tidak memunculkan pengetahuan dasar tentang hak dan tanggung jawab warga negara serta sesuai nilai dan norma dalam masyarakat dalam penyelenggaraan acara pesta laut Blanakan agar pelaksanaan sesuai dengan rencana yang diharapkan.

Dengan demikian, paradigma baru nilainilai pendidikan kewarganegaraan harus dapat mencerdaskan umat manusia dan memelihara persaudaraan serta memberikan motivasi untuk hidup bermasyarakat, berbangsa, dan bernegara yang mampu mengeksplorasi dan memanfaatkan potensi alam daerah masingmasing, seperti pada tradisi pesta laut Blanakan dalam memasuki era globalisasi sekarang ini.

Aspek civic skill (kecakapan kewarganegaraan) berawal dari karakter yang baik dari individu. Faktor yang berpengaruh pada pembentukan karakter adalah diri dan lingkungan (Haimah, 2018). Pada tradisi pesta laut Blanakan terkandung pada nilai-nilai pendidikan kewarganegaraan yakni kegiatan pesta laut itu bukan hanya sekadar terlaksana, akan tetapi masyarakat nelayan dituntut memiliki pengetahuan dasar yang diwujudkan melalui kemampuan praktik keterampilan dan kecakapan serta memerlukan waktu dan biaya yang tidak sedikit. Semua ini, agar acara kegiatan pesta laut dapat berjalan sesuai dengan tujuan yang diharapkan masyarakat nelayan.

Dengan demikian nilai Pendidikan Kewarganegaraan bertujuan untuk mengembangkan kompetensi sebagai standar atau tolak ukur terhadap kemampuan dan kecakapan dalam membangun keterampilan bagi masyarakat nelayan pada tradisi pesta laut Blanakan Seperti adanya pendidikan kewarganegaraan dari aspek keterampilan, dilihat dari hasil observasi dan wawancara bahwa kompetensi warga masyarakat Blanakan dapat dilihat dari keterampilan sosial mereka karena dengan keterampilan sosial pesta laut Blanakan bukan hanya saja menjadi kegiatan warga masyarakat sekitar tetapi menjadi keterampilan semua warga masyarakat Blanakan.

Sedangkan nilai-nilai yang terkandung dalam pesta laut Blanakan yang sehubungan dengan civic skill tersebut, seperti musyawarah, seperti dengan mengadakan pesta laut Blanakan masyarakat belajar mengatur sebuah acara untuk kegiatan tersebut, seperti mengadakan rapat dengan anggota panitia dan masyarakat nelayan sebelum melaksanakan acara, setelah itu mengatur anggaran untuk acara pesta laut, dilihat dari hasil musyawarah semua pihak anggara bisa didapat dari warga setempat, sponsor, tabungan masyarakat kepada pihak KUD Blanakan.

Nilai selanjutnya dengan mengatur waktu, acara tradisi Blanakan yang dianggap saklar ini memang menuntut masyarakat untuk lebih melihat waktu dalam pelaksanaan, seperti ketika membuang kepala kerbau pihak panitia mengadakan tepat jam 08.00 WIB, dikarenakan jika lebih dari waktu yang ditentukan akan mendatangkan marabahaya bagi masyarakat setempat. dan mengumpulkan masyarakat, pada saat perayaan pesta laut Blanakan untuk membuat kerajinan-kerajinan, perlengkapan perayaan pesta laut Blanakan kemudian membuat sesajian dan tabur bunga tergolong kedalam nilai-nilai civic skill.

Masyarakat tidak hanya mempunyai keterampilan kewarganegaraan melainkan harus mempunyai sikap keterampilan sosial, yaitu adanya kemampuan berkomunikasi dengan adanya interaksi antar warga masyarakat Blanakan yang baik proses kegiatan acara ini akan menghasilkan hubungan yang baik satu sama lain, proses komunikasi juga melancarkan kerja masyarakat dengan pihak nelayan dan panitia selain itu kegiatan ini menjalin hubungan dengan orang lain, tidak hanya warga nelayan saja yang memang merasa diuntungkan dalam acara ini, pihak masyarakat dan pemerintah daerah juga merasa bahwa acara ini bisa dijadikan icon pariwisata dan mendatangkan wisatawan.

Selain itu, acara pesta laut Blanakan saling menghargai diri sendiri dan karya orang lain dengan cara harus mampu menerima 
masukan atau pendapat dari orang lain. Seperti dalam acara pesta laut Blanakan masyarakat dituntut untuk bekerja sama dalam menghasilkan sebuah keterampilan, menghilangkan semua perbedaan demi kepentingan dan tujuan bersama agar terciptanya kegiatan pesta laut Blanakan yang sesuai dan diharapkan oleh seluruh masyarakat Blanakan.

Aspek civic disposition pada tradisi pesta laut Blanakan dapat dilihat dari cara membentuk karakter masyarakat nelayan dengan cara memberi tahu dan mengajarkan hal-hal yang baik seperti bisa menjaga ekosistem laut. Pola khusus membentuk karakter bagi masyarakat nelayan tidak ada, hanya perannya mengumpulkan masyarakat untuk diberi pengarahan oleh para tokoh budaya, namun terkadang pengarahan tersebut tidak didengar oleh masyarakat nelayan. Karena masih adanya sikap apatis dari masyarakat nelayan yang perlu dihindari, begitu pula dalam mengumpulkan masyarakat nelayan terkadang mengalami kendala kurangnya antusias.

Kendala atau kurangnya antusias para masyarakat nelayan dikarenakan tidak semua warga nelayan ikut serta membantu pelaksanaan tradisi ini, masih saja ada warga nelayan yang hanya melihat bahkan bersikap apatis atau acuh terhadap kegiatan yang dilaksanakan warga Blanakan, kurangnya pemahaman akan pentingnya menjalankan tradisi ini juga membuat warga nelayan bersikap acuh, dan tidak ikut dalam melaksanakan tradisi tersebut. Terkecuali hanya pada acara tradisi pesta laut mereka sangat antusias. Inilah yang menjadi kendala pada umumnya. Namun sikap kegotongroyongan masih kental bagi masyarakat nelayan desa Blanakan, dalam penyelenggaraan pesta laut, watak inilah yang tercermin bagi masyarakat nelayan. Hal ini sesuai dengan nilai-nilai pendidikan kewarganegaraan yang mengandung nilai sosial, gotong royong, menjalin kebersamaan, tidak individualistis selalu ada ikatan kerja sama diantara para nelayan.

Oleh karena itu, fungsi civic disposition bagi masyarakat nelayan dapat dipengaruhi oleh para tokoh budaya yang dianggap paling dominan, dalam membentuk watak dan karakter, terutama identik dengan perilaku masyarakat yang bersahaja, rasa syukur, mampu bersosialisasi, kekeluargaan, peduli lingkungan dan mempunyai nilai-nilai. Untuk membangun watak masyarakat nelayan salah satunya menanamkan sikap solidaritas, yaitu gotong royong, tujuannya agar masyarakat tetap dapat mengembangkan dan menjaga nilai-nilai tradisi secara turun-temurun serta mengaplikasikan dalam tata cara pesta laut Blanakan, mulai dari penyembelihan kepala kerbau dan lain-lainnya. Tidak semua masyarakat bisa melakukan hal itu, walaupun mereka tahu tata caranya hanya sekadar praktik, akan tetapi yang diutamakan ritualnya berupa jampi-jampi.

Pemberitahuan acara pesta laut kepada masyarakat nelayan, cukup dengan membuat umbul-umbul atau spanduk di sepanjang jalan dan lokasi yang akan dijadikan tempat dilaksanakannya upacara tersebut. Namun sesungguhnya masyarakat nelayan turut berperan aktif pada acara penyelenggaraannya, sebagai ucap rasa syukur atas rezeki yang telah dilimpahkannya kepada mereka melalui hasil laut.

Anggaran biaya pesta laut Blanakan tidak sedikit pengorbanan yang harus dikeluarkannya, ini perlu dukungan pihak sponsor, diantaranya dukungan dari pihak KUD, ada pula dari masyarakat nelayan, bahkan dari para pedagang yang ikut berpartisipasi atau menyumbangkan dananya agar meriahnya acara pesta laut Blanakan. Dengan biaya yang cukup besar, tentunya ada kegiatan hiburan lainnya seperti acara wayang kulit, sandiwara, konsumsi dan lain sebagainya. Semua acara tersebut, perlu dipersiapkan jauh-jauh hari, terutama anggaran biaya yang terkumpul dari masyarakat, pemerintah daerah pun turut membantu memberikan sumbangan sesuai dengan alokasi anggaran biaya bagi masyarakat.

Untuk menjaga dan mengenalkan nilainilai budaya pesta laut Blanakan, selalu ditularkan kepada generasi penerus agar tidak punah, terutama kaum remaja dengan cara melibatkan generasi muda dalam pelaksanaannya, karena dengan melibatkan 
para remaja, pada kegiatan pesta laut, mereka memiliki sikap dan tanggung jawab serta rasa bangga serta menghormati para pendahulunya. Bahkan menurut mereka bahwa kegiatan pesta laut Blanakan kemudian hari memiliki nilai komersial menjadi objek wisata yang potensial dan unggulan. Untuk itu diperlukan cara pengelolaannya, yang sesuai dengan konsep manajemen yang tepat sasaran, agar objek wisata dapat menjadi perhatian dunia atau memiliki nilai globalisasi.

Pesta laut Blanakan selain nilai-nilai budaya yang terdapat dalam pesta laut juga bisa menimbulkan sisi negatif dari pelaksanaan pesta laut tersebut, contohnya seseorang beranggapan bahwa laut lah yang memberikan kehidupan warga nelayan, dengan adanya ritual membuang kepala kerbau masyarakat ada yang mempercayai dewi-dewi atau hantu penghuni laut yang mereka anggap sebagai pembawa berkah.

Berdasarkan beberapa pendapat di atas dari narasumber, bahwa nilai-nilai pendidikan kewarganegaraan berkaitan dengan aspek civic disposition terlihat adanya sikap gotong royong, musyawarah, kebersamaan dan kepedulian dalam semua aspek kegiatan, terutama dalam acara tradisi pesta laut Blanakan.

Unsur ini sesungguhnya merupakan dimensi yang substantif dan esensial dalam mata pendidikan kewarganegaraan dapat dipandang sebagai muara dari pengembangan kedua dimensi sebelumnya. Watak kewarganegaraan berkaitan dengan karakter privat dan publik dari warga negara yang perlu dipelihara dan ditingkatkan dalam demokrasi konstitusional.

\section{Simpulan}

Kegiatan seremonial upacara adat pesta laut Blanakan itu bukan hanya sekadar pesta pada umumnya, tetapi memiliki nilai budaya yang sakral warisan leluhurnya. Untuk kepentingan ini masyarakat nelayan memunculkan civic knowledge tentang kebangsaan dan kewarganegaraan yang tentunya dapat diarahkan oleh para tokoh masyarakat. Nilai-nilai yang terkandung dalam pesta laut Blanakan yang sehubungan dengan civic skill, dalam acara pesta laut sejak awal hingga akhir kegiatan, selalu memerlukan kemampuan keterampilan yang cakap dalam mengorganisasikan penyelenggaraan pesta laut yang ada relevansinya antara intelektual dengan keterampilan partisipasi (partipatory skill) tidak hanya membutuhkan pengetahuan tetapi diperlukan kecakapan. Membentuk karakter masyarakat nelayan desa Blanakan dengan cara memupuk sikap gotong royong dalam penyelenggaraan pesta laut, watak inilah yang tercermin bagi masyarakat nelayan. Hal ini sesuai dengan nilai-nilai Pendidikan Kewarganegaraan yang menjadi dasar pengembangan The Ideal democratis Citizen yakni mengandung nilai sosial, gotong royong, menjalin kebersamaan, tidak individualistis selalu ada ikatan kerja sama diantara para nelayan. Hal ini terkandung pada prinsip civic disposition, membentuk watak dan karakter bangsa Indonesia.

\section{Ucapan Terima Kasih}

Terima kasih disampaikan kepada saudari Anisah mahasiswa Prodi PPKn angkatan 2013 yang telah bersama-sama mengembangkan hasil penelitian menjadi sebuah artikel, Kepala Desa Blanakan, kuncen dan masyarakat nelayan Desa Blanakan, pengurus Koperasi Unit Desa (KUD) Mandiri Mina Fajar Sidik yang membiayai setiap penyelenggaraan pesta laut Blanakan, dan aparat kepolisian yang juga turut membantu mengamankan selama kegiatan upacara Pesta Laut Blanakan.

\section{Referensi}

Aulia, S. S., Arif, D. B., \& Arpannudin, I. (2018). PPkn dan etika lingkungan hidup di sekolah adiwiyata. In Pengembangan Profesionalisme Dosen dan Guru Indonesia (Vol. 2, hal. 1-9). Malang: Univerasitas Kanjuruhan Malang.

Creswell, J. W. (2009). Research design: qualitative, quantitative, and mixed methods approaches. London: SAGE Publications.

Daeng, H. (2008). Manusia, kebudayaan, dan lingkungan: Tinjauan antropologis. Yogyakarta: Pustaka Pelajar. Diambil 
dari

https://books.google.co.id/books?id=zzt WAAAAMAAJ

Darwis, R. (2008). Hukum adat. Bandung: Laboratorium

Kewarganegaraan

Pendidikan

Pendidikan Indonesia.

Doğanay, A. (2012). A curriculum framework for active democratic citizenship education. In M. Print \& D. Lange (Ed.), Schools, Curriculum and Civic Education for Building Democratic Citizens (hal. 19-39). Roterdam, Boston, Taipe: Sense Publisher.

Halimah, L. (2018). Pendidikan kewarganegaraan dan kosmopolitan. Yogyakarta: Gosyen Publishing.

Indrawardana, I. (2012). Kearifan lokal adat masyarakat Sunda dalam hubungan dengan lingkungan alam. Komunitas, 4(1), 1-8. https://doi.org/10.15294/komunitas.v4i1 .2390

Kalidjernih, F. K. (2011). Pusparagam konsep dan isu kewarganegaraan. Bandung: Widya Aksara.

Marx, K. (1999). A contribution to the critique of politic econom (Online Ver). Moscow: Progress Publishers, Moscow.

Niode, A. S. (2007). Gorontalo: perubahan nilai-nilai budaya dan pranata sosial. Pustaka Indonesia Press.

Nygren, A. (2009). Local knowledge in the discourse. Critique of Anthropology, 19(3), 267-288.

Osler, A., \& Starkey, H. (2005). Changing citizenship. Democracy and inclusion in education. New York, NY: Open University Press. https://doi.org/10.1177/1746197906068 125

Rosidi, A. (2011). Kearifan lokal dalam perspektif budaya Sunda. Bandung: Kiblat.

Rosyadi. (2014). Sistem pengetahuan lokal masyarakat Cidaun - Cianjur Selatan sebagai wujud adaptasi budaya. Patanjala, 6(3), 431-446.
Soemantri, M. N. (2001). Menggagas pembaruan pendidikan IPS. Bandung: PT. Remaja Rosdakarya.

Supardan, D., Hasan, H., \& Rachmatika, R. (2008). Pengantar ilmu sosial: Sebuah kajian pendekatan struktural. Jakarta: Bumi Aksara.

Suyato. (2016). Belajar demokrasi di sekolah: Reorientasi pendidikan dan pengembangan kultur sekolah yang humanis. Jurnal Civics: Media Kajian Kewarganegaraan, 13(1), 83-95.

Yogi, A. S. (2013). Pesta laut nadran sebagai upaya melestarikan kearipan lokal dalam mengembangkan "civic culture" (Studi deskriptif di Desa Eretan Wetan Kabupaten Indramayu). Universitas Pendidikan Indonesia. 